\title{
ACTIN IN THE CORTICAL LAYER OF THE SEA URCHIN EGG. CHANGES IN ITS CONTENT DURING AND AFTER FERTILIZATION
}

\author{
ISSEI MABUCHI, HIROSHI HOSOYA* and HIKOICHI SAKAI* \\ Department of Biology, College of General Education, University of Tokyo, Komaba, Meguroku, Tokyo \\ 153, and *Department of Biochemistry and Biophysics, Faculty of Science, University of Tokyo, Hongo, \\ Bunkyoku, Tokyo 113, Japan
}

\begin{abstract}
Cortices were isolated from either unfertilized or fertilized sea urchin eggs with a medium capable of preserving actin-containing structures. The sections of the cortices were examined by electron microscopy. The cortices isolated from unfertilized eggs did not seem to contain filamentous structures, whereas those from fertilized eggs showed many microvillar and meshwork microfilaments. When the cortices were run in a sodium dodecyl sulfate-polyacrylamide gel, a major protein band co-migrated with rabbit skeletal muscle actin (molecular weight 42,000 ). About $50 \%$ of the 42,000 molecular weight proteins in fertilized egg cortices accounted for actin from the DNase I-binding activity in contrast to $10-20 \%$ of such components for unfertilized egg cortices. The content of actin in the cortices isolated at various stages was estimated by means of SDS-gel electrophoresis followed by gel scanning. It increased from $0.4 \%$ to $3 \%$ upon fertilization but did not seem to increase further from post-fertilization through cleavage.
\end{abstract}

KEY WORDS actin / cell cortex / sea urchin egg / fertilization / cleavage

Since the discovery of contractile ring filaments in the cleavage furrow of animal cells (24) and subsequent identification of these filaments as actin $(5,20,23)$, it has been assumed that the cleavage of these cells implies contraction of the contractile ring $(15,21,28)$.

The contractile ring is a temporarily formed structure and is only seen during telophase. In other words, it exists only when the cleavage furrow is progressing. It has been reported that the formation of the contractile ring is accomplished within $20 \mathrm{sec}$ (26). However, no one has been able to see the formation process of the contractile ring, nor does anyone even knows whether actin filaments in the contractile ring polymerize from monomeric actin or whether they are formed through a re-arrangement of pre-existent actin filaments. One, approach to the formation mechanism of the contractile ring would be to investigate where the contractile ring actin comes from. Does it come from inner cytoplasm or from the cortical layer itself?

We isolate the cortical layer from sea urchin eggs and estimate actin content in the cortical layer to clarify if there is a transfer of actin from cytoplasm to the cortical layer in order to supply a pool of actin for the formation of the contractile ring.

\section{MATERIALS AND METHODS}

\section{Biological Materials}

Sea urchins, Hemicentrotus pulcherrimus, were obtained at Cape Manazuru, and kept in an aquarium at $12^{\circ} \mathrm{C}$. Gametes were obtained by $\mathrm{KCl}$-induced spawning. Eggs were washed with filtrated ordinary sea water, dejellied at $\mathrm{pH} 5.0$, rewashed with filtrated sea water and inseminat- 
ed. Fertilization membranes were removed as described previously (17), using calcium-free sea water containing $3 \mathrm{mM}$ cysteine and $8 \mathrm{mM}$ EDTA to make the membrane elevate high, and filtering through a sheet of $74 \mu \mathrm{m}$-nylon mesh. Eggs were washed with and cultured in calciumfree sea water with a continuous swirling. At a desired time, they were washed quickly with more than $10 \mathrm{vol}$ of an isolation medium. The isolation medium consisted of $0.1 \mathrm{M} \mathrm{KCl}, 5 \mathrm{mM}$ $\mathrm{MgCl}_{2}, 2 \mathrm{mM}$ ethylene glycol bis-( $\beta$-aminoethyl ether)- $N, N^{\prime}$-tetraacetic acid (EGTA), $0.5 \mathrm{mM}$ phenylmethylsulfonyl fluoride or $10 \mathrm{mM} p$-tosyl arginine methylester, $0.2 \mathrm{mM}$ dithiothreitol and $10 \mathrm{mM} 2$ ( $N$-morpholino)-ethane sulfonic acid (MES) buffer (pH 6.2-6.5), or piperazine- $N$, $N^{\prime}$-bis(2-ethane sulfonic acid) (PIPES) buffer (pH 6.8) or $N$-tris(hydroxymethyl) methyl-2aminoethane sulfonic acid buffer ( $\mathrm{pH} 7.2-7.5$ ). Sometimes $0.5 \mathrm{mM}$ ATP was included in the medium.

Washed eggs were resuspended in more than 10 vol of the isolation medium and homogenized with a hand-driven Teflon-glass homogenizer. Disruption of eggs was checked with a Nikon phase contrast microscope. When all eggs were disrupted leaving the cortical hulls, the suspension was centrifuged at $500 \mathrm{~g}$ for $10 \mathrm{sec}$ to pellet the cortices. They were washed repeatedly with the isolation medium by suspension and brief centrifugation until the supernatant became clear.

Rabbit skeletal muscle actin was prepared according to Spudich and Watt (33).

\section{Extraction of Actin from Cortices}

To the isolated cortices was added 0.25 vol of $3 \mathrm{M}$ KI containing $20 \mathrm{mM}$ dithiothreitol. The mixture was kept standing at $0^{\circ} \mathrm{C}$ for $1 \mathrm{hr}$ and then centrifuged at $10,000 \mathrm{~g}$ for $15 \mathrm{~min}$ to remove insoluble materials.

\section{DNase I-Affinity Chromatography}

An $0.3 \mathrm{ml}$ column of DNase I-bound Sepharose 4B (Worthington Biochem. Corp., lot no., 39D639) was washed successively with $3 \mathrm{M}$ guanidine $\cdot \mathrm{HCl}$ (Schwarz/Mann) and $0.6 \mathrm{M}$ $\mathrm{KI}$, both of which had been dissolved in a solution containing $2 \mathrm{mM}$ MES buffer (pH 6.8) and $0.5 \mathrm{mM}$ dithiothreitol. The $0.6 \mathrm{M} \mathrm{KI}$-extract ( 3 to $4 \mathrm{mg}$ protein) was applied to the column. The flow through fraction was reapplied to the column to ensure thorough binding of actin to DNase I. The column was then washed successively with $0.6 \mathrm{M} \mathrm{KI}$ and $0.75 \mathrm{M}$ guanidine.
$\mathrm{HCl}$ and then eluted with $3 \mathrm{M}$ guanidine $\cdot \mathrm{HCl}$ to recover actin (10).

\section{Sodium Dodecyl Sulfate-Polyacrylamide Gel Electrophoresis}

All sample solutions for electrophoresis were diluted with a solution of $8 \mathrm{M}$ urea, $0.5 \%$ sodium dodecyl sulfate (SDS), $0.1 \mathrm{M} \beta$-mercaptoethanol, $10 \mathrm{mM}$ EDTA, and $20 \mathrm{mM}$ Tris $\cdot \mathrm{HCl}(\mathrm{pH} 8.2)$ and boiled for $3 \mathrm{~min}$. Gel electrophoresis in the presence of SDS was performed in a $10 \%$ polyacrylamide slab gel as described by Laemmli (9). Gels were stained with $0.025 \%$ Coomassie brilliant blue dissolved in 10\% (v/v) acetic acid and $25 \%(\mathrm{v} / \mathrm{v})$ isopropanol, and destained in 10\% acetic acid. They were scanned with a Shimadzu CS-910 chromatoscanner with a dual wavelength equipment. The area of the peaks was selected as described previously (18) and monitored with a Numonics digitizer model 1250 .

Marker proteins used for molecular weight estimation were rabbit skeletal muscle myosin heavy chain (molecular weight, 200,000), rabbit muscle phosphorylase $a$ (m.w., 94,000), bovine serum albumin (m.w., 68,000), sea urchin flagellar tubulin (m.w., 55,000), rabbit skeletal muscle actin (m.w., 42,000), bovine erythrocyte carbonic anhydrase (m.w., 30,000) and soybean trypsin inhibitor (m.w., 20,000).

\section{Electron Microscopy}

Isolated cortices were sedimented at $1,500 \mathrm{~g}$ for $10 \mathrm{~min}$ and fixed with $2.5 \%$ glutaraldehyde dissolved in the isolation medium for $1 \mathrm{hr}$ at $0^{\circ} \mathrm{C}$. Post-osmification was carried out with $4 \mathrm{mM} \mathrm{OsO}_{4}, 50 \mathrm{mM} \mathrm{KCl}, 5 \mathrm{mM} \mathrm{MgCl}_{2}$ and 50 $\mathrm{mM}$ sodium phosphate buffer for $20 \mathrm{~min}$ at $0^{\circ} \mathrm{C}$ (19). All samples were embedded in Rigolac mixture after dehydration with acetone (8). Sections were cut on a Porter-Blum microtome (Ivan Sorvall, Inc.), stained with uranyl acetate and lead citrate, and viewed with a Hitachi HS-9 electron microscope.

\section{Protein Determination}

Protein was determined by the method of Lowry et al. (11). Prior to determination, cortices were diluted with a solution of $1 \%$ SDS, $2 \mathrm{mM}$ EGTA, $10 \mathrm{mM}$ PIPES buffer (pH 6.85) containing $0.5 \mathrm{mM}$ phenylmethylsulfonyl fluoride or $10 \mathrm{mM} p$-tosyl-L-arginine methylester and sonicated with a ultrasonic generator U0300FB (Kokusai Electric Co.). Proteins in the frac- 


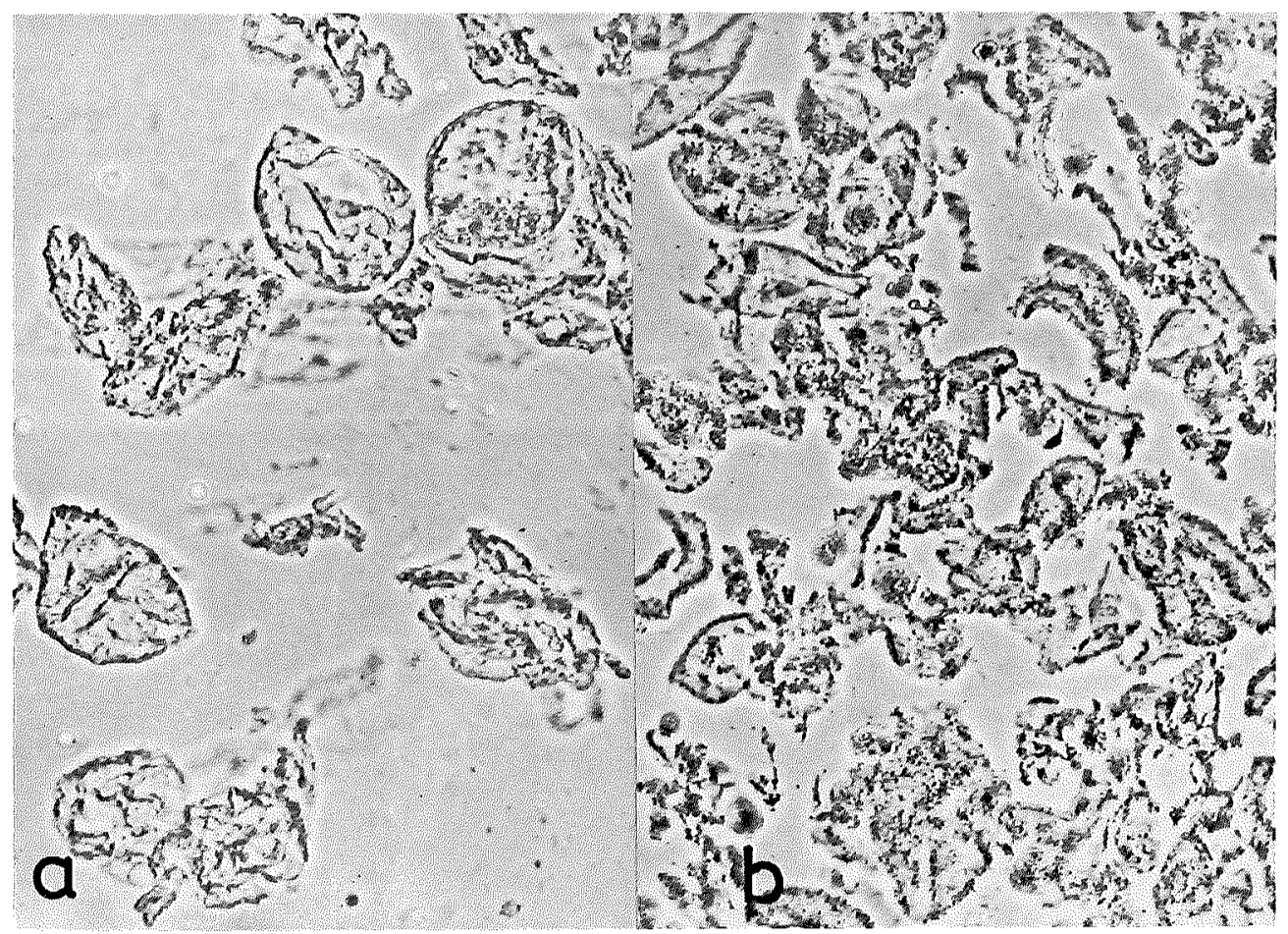

Fig. 1 Isolated cortices. a, from unfertilized eggs. b, from fertilized eggs. $\times 330$

tions recovered from the DNase I column were precipitated with $6 \%$ trichloroacetic acid in the presence of $0.017 \%$ sodium deoxycholate (2).

\section{RESULTS}

\section{Microscopic Appearance of the Isolated Cortices}

Unfertilized eggs autolysed in the isolation medium. This autolysis seemed to depend on the temperature. It occurred in a short time at room temperature but took about $10 \mathrm{~min}$ at $04^{\circ} \mathrm{C}$. A part of the egg disrupted abruptly and the cytoplasm began to be discharged. The cortices appeared to contract actively so as to push the cytoplasm out. The autolysis lasted until all the cytoplasm was excluded. The inclusion of ATP in the isolation medium did not affect the autolysis at all. Under a light microscope, the isolated unfertilized egg cortices looked like an unfragmented ghost (Fig. 1a). On the other hand, fertilized eggs did not autolyse. It seemed that they were more resistant to the osmotic shock than unfertilized eggs. The cortices obtained from the fertilized eggs were prone to fragmentation during homogenization (Fig. 1b).
Electron microscopic observations revealed that the cortex isolated at $\mathrm{pH} 6.8$ from the unfertilized egg was composed of a vitelline coat, plasma membrane, cortical granules and small vesicles (Fig. 2a). Morphology of the micropapillae seemed to be retained as indicated in the figure. These cortices were packed by the centrifugal force before fixation and lost their spherical appearance. Therefore, it was not easy to distinguish individual corticies. No filamentous structure was detected in any region of these cortices.

In contrast to the cortices from unfertilized eggs, those isolated at pH 6.8 from fertilized eggs ( $30 \mathrm{~min}$ post-fertilization) consisted of three distinct layers, outermost, middle and innermost layers (Fig. 2b). The outermost layer was composed of numerous small elongated circles of membranes, which were identified as sectioned microvillar membranes. Between this layer and the middle layer was the plasma membrane. Sometimes the microvilli originating from the plasma membrane were cross-sectioned (Fig. 2c). Each microvillus had a 'root' which extended into the middle layer of the isolated cortices. This root seemed to be composed of a bundle of microfilaments. These filaments were anchored 


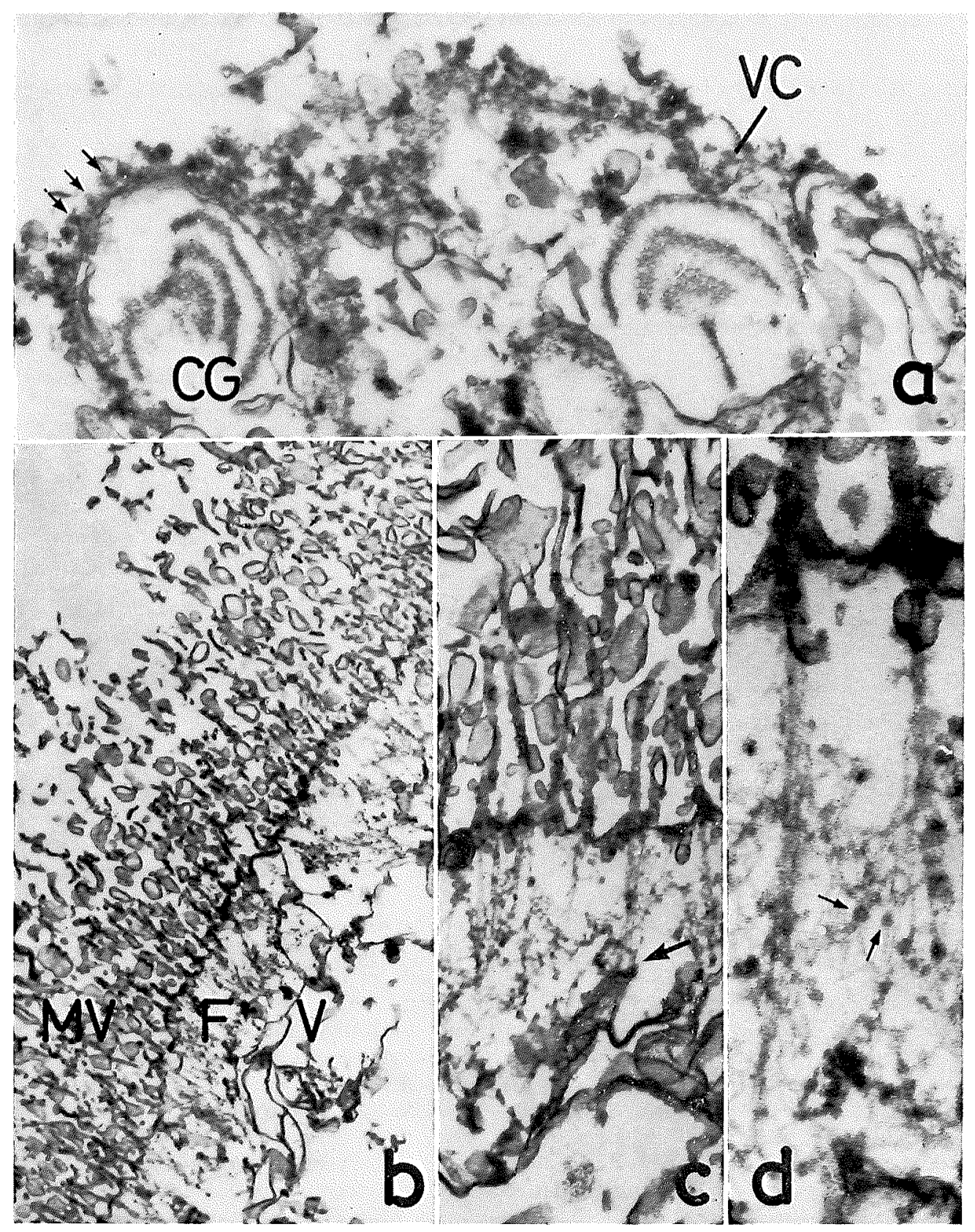

Fig. 2 Cross sections of isolated cortices. a, from an unfertilized egg. Arrows indicate micropapillae. CG, cortical granule. VC, vitelline coat, $\times 25,000$. $b-c$, from fertilized eggs. Arrow in $b$ indicates the attachment of filaments to a part of the vesicle. Arrow in $c$ indicates granules. MV, microvillar region. F, filamentous layer. V, vesicular layer, b, $\times 14,000 . c, \times 40,000 . d, \times 100,000$

at their cytoplasmic ends to the upper part of the vesicular material of the innermost layer. Other components of the middle layer were also thin filaments which were rather randomly oriented and formed a meshwork, and were sometimes continuous with the root of the microvillus (Fig. 2, c and d). Some unidentified particles of about $20 \mathrm{~nm}$ in diameter were attached to both 
of these filaments. The innermost layer was composed of large vesicles. This layer, together with the middle filamentous layer, composed the cortical layer of the egg. The thickness of the middle filamentous layer was about $0.8 \mu \mathrm{m}$ and the overall thickness of the cortical layer was 1.5 to $2 \mu \mathrm{m}$.

\section{Protein Species in the Cortices from Unfertilized and Fertilized Eggs}

The gel electrophoretic system we employed covered proteins of molecular weight from 20,000 to a little larger than 200,000. About 70 protein components were detected in both unfertilized and fertilized egg cortices. Among them, only seven protein species (protein 1 to 7 in Fig. 3) showed a remarkable change in content upon fertilization or from fertilization through the two-cell stage. Protein 1 (molecular weight, a little larger than 200,000 ) did not seem to be present in the unfertilized egg cortex, but appeared and increased in amount after fertilization up to 52 min (streak stage). Proteins 2 (m.w., almost 200,000), 4 (m.w., 110,000) and 5 (m.w., 74,000 ), which were major proteins in the unfertilized egg cortex, vanished or were reduced markedly in their amounts after fertilization. A protein component which co-migrated with protein 1 reappeared at about $30 \mathrm{~min}$ after fertilization and reached a maximum in content at 52 min. Protein 3 seemed to decrease gradu-

U 1327528097117

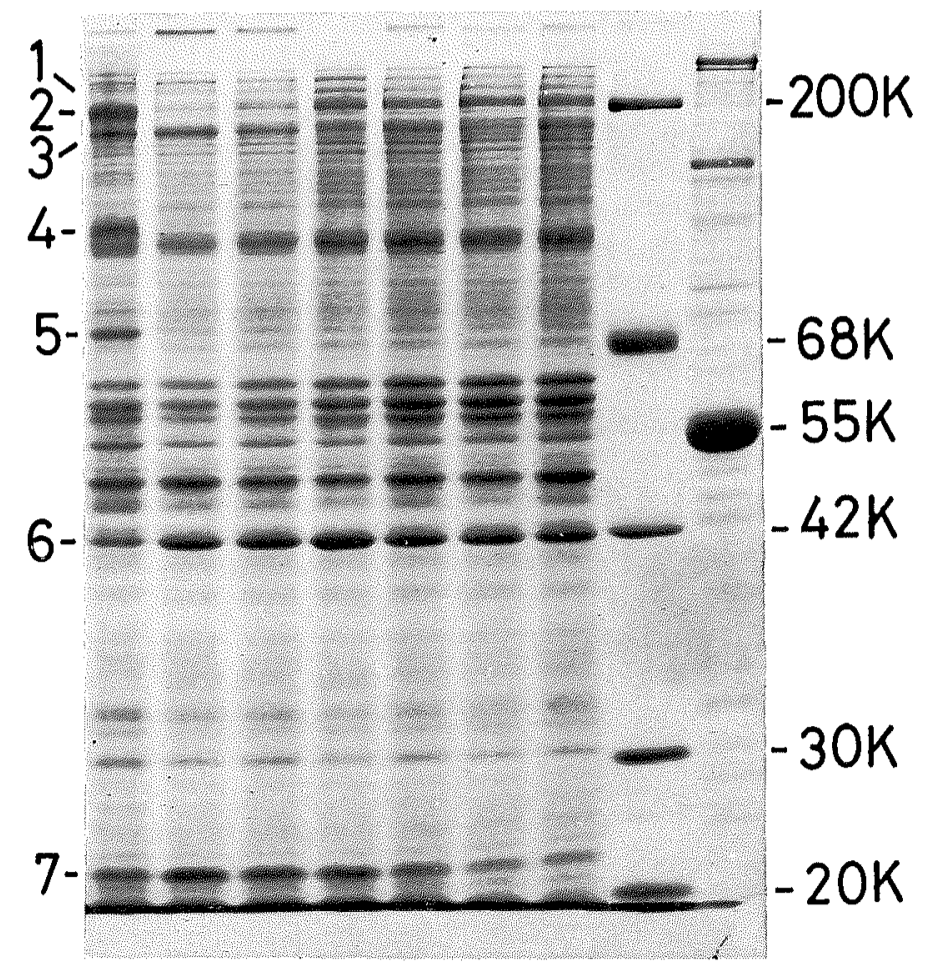

Fig. 3 Electrophoretic patterns of isolated cortices. Eggs were cultured at $18^{\circ} \mathrm{C}$. Figures on the top of the gel indicate time after fertilization. Thirty $\mu \mathrm{g}$ of protein were loaded onto each of these columns. U, unfertilized egg cortices. Forty-eight $\mu \mathrm{g}$ of protein were loaded. Figures on the right-hand side of the gel indicate molecular weight $\times 10^{-3}$. The extreme right-hand column, flagellar axonemes from Hemicentrotus sperm, the main band of which represents tubulin. The second column from the right, a mixture of rabbit skeletal myosin and actin, bovine serum albumin, bovine erythrocyte carbonic anhydrase, and soybean trypsin inhibitor. Proteins in the cortices which changed in content are marked on the left-hand side of the gel. This gel was used to estimate the $42 \mathrm{~K}$ protein content in an experiment shown in Fig. 4e (ATP present). 
ally after fertilization. Protein 6 , which was the most prominent protein in the cortices of fertilized eggs and co-migrated with skeletal muscle actin (m.w., 42,000), increased in amount upon fertilization. Protein 7 (m.w., 22,000) was gradually reduced in amount after fertilization but did not seem to change further after 80 min (metaphase) post-fertilization.

\section{The Content of Actin in the Isolated Cortices}

As mentioned in the preceding section, protein 6 which co-migrated with actin in an SDS-gel was the most prominent protein in the cortices from fertilized eggs. We estimated the net amount of actin in this component by utilizing the property of actin to bind DNase I. Cortices were extracted with $0.6 \mathrm{M}$ KI. Since KI totally depolymerizes actin filaments, we assumed that all actin in the cortex would have been extracted by this treatment. Fifty nine and $79 \%$ of the 42,000 molecular weight $(42 \mathrm{~K})$ proteins in the cortices of unfertilized and fertilized eggs (30 min post-fertilization), respectively, were extracted by this treatment. The extracts were passed through a DNase I-bound Sepharose 4B column. Absorbed proteins were eluted with $3 \mathrm{M}$ guanidine $\cdot \mathrm{HCl}$.

Actin in the cortex can be estimated by either of the two procedures:

$$
\begin{aligned}
& \text { Cortical actin content }(\%) \\
& =\frac{42 \mathrm{~K} \text { in Applied KI-extr. }-42 \mathrm{~K} \text { in FT }}{\text { Applied KI-extr. }} \\
& \times \frac{\text { KI-extr. }}{\text { Cortex }} \times 100 \ldots \ldots \ldots \ldots \ldots \ldots \ldots \ldots \ldots . . . \ldots \ldots \\
& (\text { Applied KI-extr. }- \text { FT) } \\
& \times \frac{42 \mathrm{~K}(\%) \text { in GCl }}{\text { Applied KI-extr. }} \times \frac{\text { KI-extr. }}{\text { Cortex }} . . . . \ldots \ldots . . .
\end{aligned}
$$$$
\text { or }
$$

where $42 \mathrm{~K}$ stands for $42 \mathrm{~K}$ protein. FT and $\mathrm{GCl}$ represent the flow through fraction and $3 \mathrm{M}$ guanidine $\cdot \mathrm{HCl}$ eluate from the DNase column, respectively. All the abbreviated words in the equations represent protein amounts in these fractions. Using equation 1, the actin contents in the isolated cortices were estimated to be $0.4 \%$ and $3.0 \%$ for unfertilized and fertilized eggs, respectively. Using equation 2, they were $0.3 \%$ and $2.2 \%$, respectively (Table 1 ). Since the content of $42 \mathrm{~K}$ proteins in the cortex were 2.2 and $5.6 \%$ for unfertilized and fertilized eggs, respectively, actin occupied $10-20 \%$ and $40-50 \%$ of $42 \mathrm{~K}$ proteins of unfertilized and fertilized egg cortices, respectively.
Table 1 Recovery of Proteins and Percentage of $42 \mathrm{~K}$ Proteins in Fractions Obtained by DNase I-Affinity Chromatography

\begin{tabular}{lcc}
\hline $\begin{array}{l}\text { Protein amount in } \\
\text { each fraction }(\mathrm{mg})\end{array}$ & $\begin{array}{c}\text { Unfertilized } \\
\text { egg }\end{array}$ & $\begin{array}{c}\text { Fertilized } \\
\text { egg }\end{array}$ \\
\hline Cortex & 8.69 & 6.46 \\
KI-extract & 5.89 & 4.46 \\
KI-extract applied & 4.44 & 3.37 \\
to the column & 4.10 & 2.95 \\
Flow through & & \\
\hline Percentage of 42K protein $(\%)$ & 5.6 \\
\hline Cortex & 2.2 & 6.2 \\
KI-extract & 2.1 & 2.2 \\
Flow through & 1.6 & 25.6 \\
3 M GCl eluates & 4.8 & \\
\hline
\end{tabular}

Cortices were extracted with $0.6 \mathrm{M} \mathrm{KI}$ as described in Materials and Methods and a portion of the extract was applied to a $0.3 \mathrm{ml}$ column of DNase I-bound Sepharose 4B. The flow through fraction and $3 \mathrm{M}$ guanidine $\mathrm{HCl}$ eluates were recovered. A $0.75 \mathrm{M}$ guanidine $\cdot \mathrm{HCl}$ wash was neglected because of the small protein amount. These values were used in the calculation of the actin content in the isolated cortices as described in the text.

\section{Change in the Content of Actin in the Cortex upon and after Fertilization}

As mentioned above, there was a significant difference between the actin contents in the isolated cortices from unfertilized and fertilized eggs. To investigate the change in detail, we isolated cortices from eggs at various stages of division cycle. There are some reports indicating that, in some cases, intracellular actin polymerization may be a function of intracellular $\mathrm{pH}$ : increase in $\mathrm{pH}$ from 6.5 to 7.5 favors actin polymerization in the cortical layer of the sea urchin egg (1) or increase in pH caused by an ionophore-induced actin polymerizaticn in echinoderm sperm acrosomes (34). Thercfore, we used the isolation media of various $\mathrm{pHs}$ to catch any possible artificial effect of $\mathrm{pH}$ on the actin content of the isolated cortices.

The results are summarized in Fig. 4. The content of $42 \mathrm{~K}$ proteins increased from 2 to $5 \%$ within $20 \mathrm{~min}$ after fertilization and did not seem to change further up to the two-cell stage. Therefore, it may be reasonable to conclude that the actin content in the cortical layer did not change significantly after fertilization through cleavage. The percentage of actin in $42 \mathrm{~K}$ proteins was high enough to draw this conclusion. 


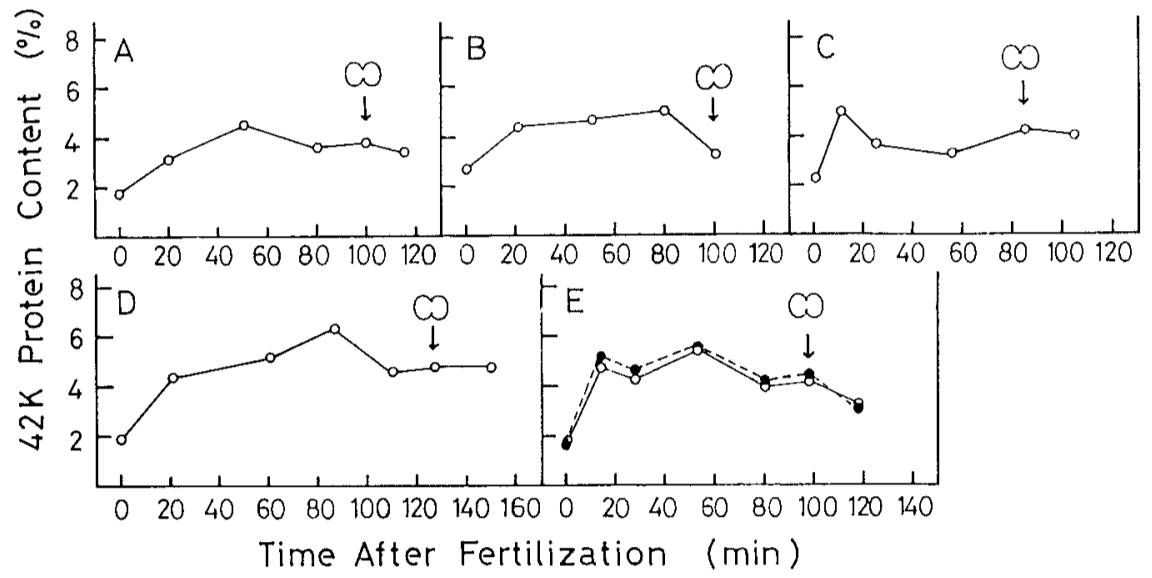

Fig. 4 Changes in the content of $42 \mathrm{~K}$ proteins in the isolated cortices. Cortices were isolated at various time of division cycle and the content of $42 \mathrm{~K}$ proteins was determined by SDS-gel electrophoresis followed by gel scan. A, cortices were isolated at pH 6.2. Culture temperature, $17.5^{\circ} \mathrm{C}$. B, isolated at $\mathrm{pH} 6.5$. Culture temperature, $17.5^{\circ} \mathrm{C}$. C, isolated at pH 6.8. Culture temperature, $20^{\circ} \mathrm{C}$. D, isolated at $\mathrm{pH} \mathrm{7.2.} \mathrm{Culture} \mathrm{temperature,} 14^{\circ} \mathrm{C}$. $\mathrm{E}$, isolated at $\mathrm{pH} 7.5 \mathrm{in}$ the absence (-_- -) or in the presence (-O- $)$ of $0.5 \mathrm{mM}$ ATP. Culture temperature, $18^{\circ} \mathrm{C}$. The onset of cleavage is indicated by arrows.

Neither a change in $\mathrm{pH}$ from 6.2 to 7.5 nor the presence of ATP affected this result. When $50 \mathrm{mM} \mathrm{KCl}$ was removed from the isolation medium, some changes in the protein composition were observed but the content of actin was not affected.

\section{DISCUSSION}

As early as 1960 , Sakai succeeded in the mass isolation of the cortical layer from the sea urchin egg using $0.1 \mathrm{M} \mathrm{MgCl}_{2}$ (22), and since then similar methods have been used to isolate the cortical layer from sea urchin (17) and starfish eggs (12). However, it was suspected that some denaturation of the structural proteins might have occurred because of the high $\mathrm{Mg}^{2+}$ concentration. In fact, for example, an actinactivated ATPase activity of egg myosin purified from isolated starfish egg cortices was not detected (12), although such an activation of egg myosin was clearly demonstrated when it was purified from whole eggs without a high concentration of $\mathrm{Mg}^{2+}$ (13).

The isolation medium we used in this report was designed to be close to the ionic condition in marine eggs to avoid the above denaturation problem. Actually, the structure of the cortical layer of both the unfertilized and fertilized eggs seems to have been retained, although some damage caused by centrifugation might have occurred in the cortices isolated from unfertilized eggs. The overall thickness of the cortices of the fertilized eggs $(1.5-2 \mu \mathrm{m})$ is a little smaller than that obtained from cortices isolated by the $\mathrm{Mg}^{2+}$-method (17) or that obtained by micromanipulation of the sea urchin egg (6).

A filamentous structure was not observed in the cortex isolated from an unfertilized egg. This is consistent with the results reported by Begg and Rebhun (1) and Spudich and Spudich (31). Begg and Rebhun (1) showed that change in the $\mathrm{pH}$ of the isolation medium dramatically affects the ultrastructure of the cortex isolated from an unfertilized egg. At $\mathrm{pH}$ 6.5-6.7, the cortex did not contain filaments like our preparation obtained at $\mathrm{pH} 6.8$. However, when isolated at $\mathrm{pH} 7.3-7.5$, numerous filaments appeared so that the cortex isolated from an unfertilized egg was indistinguishable from the fertilized egg cortex with regard to the appearance of the filamentous structures. It should be noted that these $\mathrm{pH}$ 's were the same as reported intracellular $\mathrm{pH}$ 's of the unfertilized and fertilized eggs, respectively (30). Moreover, they showed that filaments newly appeared in the cortex which had previously been isolated at pH 6.5 and then transferred to a $\mathrm{pH} 7.5$ medium. These results indicate that in the unfertilized egg cortex there is a pool of unpolymerized actin which is capatle of polymerizing when the $\mathrm{pH}$ is raised. Spudich and Spudich (31) also showed that a considerable amount of nonfilamentous actin can be detected in the unfertilized egg 
cortex.

However, the actin content of the unfertilized egg cortex was very low as compared with that of the fertilized egg cortex. We obtained values of 0.3 to $0.4 \%$ and 2.2 to $3.0 \%$, respectively. It should be noted that these are minimal values which assume that all actin in the extract can bind to DNase I. There may be some actin which did not bind to the DNase column because of a low efficiency of the column we used. But still the contents of $42 \mathrm{~K}$ proteins in these cortices were about 2 and $5 \%$, respectively, the former being significantly less than the latter. Spudich and Spudich (31) have also reported an increase in actin content upon fertilization in cortices isolated by a different procedure. The possibility, however, cannot be excluded that some of the monomeric actin is lost from the unfertilized egg cortex during isolation.

The above results seem to suggest that actin which had been distributed in the cytoplasm was partly transferred to the cortical layer upon fertilization. One of the dramatic events which occur at fertilization is an elongation of microvilli (29). Each microvillus has a bundle of actin filaments as a core (3). The appearance of the microfilamentous structures as confirmed by other authors $(1,31,32$, this report) indicates that the migration of actin from cytoplasm to the cortical layer involves a polymerization process, which probably becomes activated immediately after fertilization. That actin monomers polymerize into bundles of filaments is supported by the experimental results that actin naracrystals like the microvillar core (32) are formed in the soluble actin fraction prepared from unfertilized sea urchin eggs upon raising the temperature $(7,18)$ or raising the concentration (15). However, it may be that changes in $\mathrm{pH}$ alone do not necessarily cause actin polymerization directly in vivo because solubilized actin from Triton-treated cortical fragments of the eggs (31) or actin in the high-speed supernatant from unfertilized eggs (18) does not polymerize under the routine polymerizing conditions with a raised $\mathrm{pH}(7.5-8.0)$.

Upon fertilization, the cortical layer shows a dramatical structural change prior to the elongation of the microvilli, that is, the breakdown of the cortical granules to form fertilization membranes and the hyaline layer (4). Several proteins in the cortical layer are reduced in amount or vanish upon fertilization, the molecular weights of which are 200,000,110,000 and 74,000. These proteins may be the component of the cortical granule and/or vitelline coat.
Protein 2 (m.w., 200,000) seems to reappear after fertilization and reach a maximum in amount $52 \mathrm{~min}$ after fertilization around the streak stage. It is not conceivable that the same protein reappears in the cortical layer. This newly appeared component showed an electrophoretic mobility almost identical to that of the skeletal myosin heavy chain and it is plausible to think of it as the heavy chain of egg myosin. Increase in amount of this protein may be consistent with the speculation that myosin migrates from cytoplasm to the cortical layer at the time of cytokinesis to have a share in the formation of the contractile ring (16). One more high molecular weight protein (protein 1) also increases in amount after fertilization. This protein shows a mobility in an SDS-gel a little bit slower than that of myosin. From the apparent molecular weight, it may be an actinbinding protein which participates in the gelation of the sea urchin egg extract (7).

The appearance of the contractile ring at telophase (see reference 28) is a remarkable change in the structure of the cortex since numerous actin filaments align in the form of a circular arc parallel to the equatorial cortical layer in a very short time (in $20 \mathrm{sec}$ in the case of the Arbacia punctulata eggs, reference 26). In contrast to an 8-fold increase of actin in the cortex upon fertilization, there seemed to be no significant change in actin during division cycle. Here, it is necessary, before drawing any conclusions, to consider whether we can detect by the present assay method a possible increase in actin content of the cortex due to new formation of the contractile ring. The number of actin filaments in the contractile ring can be calculated using parameters estimated by Schroeder. From the depth $(0.15 \mu \mathrm{m})$ and width $(10 \mu \mathrm{m})$ of the ring (26) and the spacing of the filaments $(15 \mathrm{~nm}$, references 24 and 25), the number of actin filaments was calculated to be 7,700 (12). Taking the maximal diameter of the contractile ring as $94 \mu \mathrm{m}$ which is the diameter of a Hemicentrotus egg (23), and the spacing of an actin monomer in a single strand of a double helical filament as $5.5 \mathrm{~nm}$, there would be $8 \times 10^{8}$ actin molecules in a contractile ring of a Hemicentrotus egg. The total number of actin monomer in an egg is estimated to be $187 \times 10^{8}$ by taking the actin concentration in the Strongylocentrotus purpuratus egg as $3 \mathrm{mg} / \mathrm{ml}$ (18). Therefore, the contractile ring actin occupies $4 \%$ of total egg actin. This value should be compared with the amount of actin in the cortex. To do this, the amount of actin contained in microvilli on the 
surface of the egg is first estimated. Schroeder (29) estimates the density of the microvilli on the surface of a fertilized Strongylocentrotus droebachiensis egg to be $3.6 / \mu^{2}$. If the Hemicentrotus egg has the same density as the $S$. droebachiensis egg does, the number of the microvilli for a Hemicentrotus egg would be $10^{5}$. Each actin bundle in the microvillus of the Hemicentrotus egg seems to penetrate into the cortical layer up to $0.8 \mu \mathrm{m}$. Therefore, the overall length of a microvillar actin core should be the sum of the length of the microvillus and the 'root' $(0.8 \mu \mathrm{m})$. Observations by Schroeder (29) show that the burst of elongation of the microvilli occurs twice after fertilization. After the second burst, the average length of the microvilli of an $S$. droebachiensis egg becomes $1.8 \mu \mathrm{m}$. The microvilli of the Hemicentrotus egg (Fig. 2b) appear to have a length similar to those of the $S$. droebachiensis egg. Each microvillus of an $S$. purpuratus egg contains 6.78 (an average number) actin filaments (3). Using these values and assuming the length of the microvillus of the Hemicentrotus egg to be as long as $2 \mu \mathrm{m}$, the number of actin molecules composing the whole microvillar cores of the Henicentrotus egg would be $7 \times 10^{8}$, which corresponds to $4 \%$ of the total actin in the egg. Therefore, the actin content of the contractile ring and that of whole microvilli are incidentally comparable with each other.

Secondly, we estimate the amount of actin in the cortical layer excepting microvilli, although few data are available. For the Hemicentrotus egg, an isolated fertilized egg cortex shows a thickness of 1.5 to $2 \mu \mathrm{m}$, which indicates that the volume of the isolated cortex corresponds to $10 \%$ of the total. The sum of this volume and that of microvillar actin is $14 \%$ as a maximal estimate. The estimated amount of contractile ring actin (4\%) is large enough for detection by the assay method used in the present work. Therefore, if actin in the interior cytoplasm migrates into the cortical layer to construct the contractile ring before cleavage, it should be possible to detect the increase. However, we could not find any such an increase in the actin content before cleavage. It may be reasonable to conclude that the formation of the contractile ring is probably achieved by using an actin pool in the cortex itself. The problem of whether the contractile ring is formed by polymerization of monomeric actin or merely by a rearrangement of pre-existent actin filaments remains to be demonstrated.
This research was supported by a grant-in-aid from the Ministry of Education, Science and Culture (No. 421308) given to I. M. We are grateful to Ms $\mathrm{S}$. Endo for advice in electron microscopy.

\section{Recieved for publication 20 August 1980}

\section{REFERENCES}

1. BegG D. A. and RebHun L. I. (1979) pH regulates the polymerization of actin in the sea urchin egg cortex. J. Cell Biol. 83, 241-248

2. Bensadoun A. and Weinstein D. (1976) Assay of proteins in the presence of interfering materials. Anal. Biochem. 70, 241-250

3. Burgess D. R. and Schroeder T. E. (1977) Polarized bundles of actin filaments within microvilli of fertilized sea urchin eggs. J. Cell Biol. 74, 1032-1037

4. ENDo Y. (1961) Changes in the cortical layer of sea urchin eggs at fertilization as studied with the electron microscope. I. Clypeaster japonicus. Exptl. Cell Res. 25, 383-397

5. Forer A. and Behnke O. (1972) An actin-like component in spermatocytes of a crane fly (Nephrotoma suturalis Loew). II. The cell cortex. Chromosoma (Berl.) 39, 175-190

6. Hiramoto Y. (1957) The thickness of the cortex and the refractive index of the protoplasm in sea urchin eggs. Embryologia 3, 361-374

7. KANE R. E. (1975) Preparation and purification of polymerized actin from sea urchin egg extracts. J. Cell Biol. 66, 305-315

8. KusHidA H. (1960) A new polyester embedding method for ultrathin sectioning. J. Electron Microsc. 9, 113-116

9. LAEMmLi U. K. (1970) Cleavage of structural proteins during the assembly of the head of bacteriophage T4. Nature 227, 680-685

10. LINDBERG U. (1974) DNase-I inhibitor protein. Isolation with DNase-agarose. In Methods in Enzymology Vol, 34 (ed. JACOBY W. B. and Wilchek M.), Academic Press, New York, pp. $517-520$

11. Lowry O. H., Rosebrough N. J., Farr A. L. and Randall R. J. (1951) Protein measurement with the Folin phenol reagent. J. Biol. Chem. 193, 265-275

12. Mabuchi I. (1974) A myosin-like protein in the cortical layer of cleaving starfish eggs. $J$. Biochem. 76, 47-55

13. Mabuchi I. (1976) Myosin from starfish egg: properties and interaction with actin, $J . \mathrm{Mol}$. Biol. 100, 569-582

14. MaBuCHI I. (1979) Role of myosin and actin in cell division of echinoderm eggs. In Cell Motility: Molecules and Organization (ed. Hatano S., Ishikawa H. and Sato H.), University of Tokyo Press, Tokyo, pp. 147-163

15. Mabuchi I. (1979) Cytoskeleton and cell motility: Cytokinesis. Proc, $50 \mathrm{th}$ Amt. Meet. 
Zool. Soc. Japan, Zool. Mag. 88, 693 (in Japanese)

16. Mabuchi I. and OKuno M. (1977) The effect of myosin antibody on the division of starfish blastomeres. J. Cell Biol. 74, 251-263

17. Mabuchi I. and SaKaI H. (1972) Cortex protein of sea urchin eggs. I. Its purification and other protein components of the cortex. Dev. Growth and Differ. 14, 247-261

18. Mabuchi I. and Spudich J. A. (1980) Purification and properties of soluble actin from sea urchin eggs, J. Biochem. 87, 785-802

19. Maupin-Szamier P. and Pollard T. D. (1978) Actin filament destruction by osmium tetroxide. J. Cell Biol. 77, 837-852

20. Perry M. M., John H. A. and Thomas N. S. T. (1971) Actin-like filaments in the cleavage furrow of newt egg. Exptl. Cell Res. 65, 249-253

21. RAPPAPORT R. (1971) Cytokinesis in animal cells. Int. Rev. Cytol. 31, 169-213

22. Sakai H. (1960) Studies on sulfhydryl groups during cell division of sea urchin egg. II. Mass isolation of the egg cortex and change in its - $\mathrm{SH}$ groups during cell division. $J$. Biochem. Biophys. Cytol. 8, 603-607

23. SAKAI H. (1978) The isolated mitotic apparatus and chromosome motion. Int. Rev. Cytol. 55, $23-48$

24. Schroeder T. E. (1968) Cytokinesis: filaments in the cleavage furrow. Exptl. Cell Res. 53, $272-276$

25. Schroeder T. E. (1970) The contractile ring. I. Fine structure of dividing mammalian (HeLa) cells and the effects of cytochalasin B. $Z$. Zellforsch. 109, 431-449

26. Schroeder T. E. (1972) The contractile ring. II. Determining its brief existence, volumetric changes, and vital role in cleaving Arbacia eggs. J. Cell Biol. 53, 419-434

27. Schroeder T. E. (1973) Actin in dividing cells: contractile ring filaments bind heavy meromyosin. Proc. Nat. Acad. Sci. USA 70, 16881692

28. Schroeder T. E. (1975) Dynamics of the contractile ring. In Molecules and Cell Movemen (ed. Inoue S. and Stephens R. E.) Raven Press, New York, pp. 305-334

29. Schroeder T. E. (1978) Microvilli on sea urchin eggs: a second burst of elongation. Dev, Biol. 64, 342-346

30. Shen S. S. and Steinhardt R. A. (1978) Direct measurement of intracellular $\mathrm{pH}$ during metabolic derepression of the sea urchin egg. Nature 272, 253-254

31. Spudich A. and Spudich J. A. (1979) Actin in Triton-treated cortical preparations of unfertilized and fertilized sea urchin eggs. J. Cell Biol. 82, 212-226

32. Spudich J. A. and Amos L. A. (1979) Structure of actin filament bundles from microvilli of sea urchin eggs. J. Mol. Biol. 129, 319-331

33. Spudich J. A. and Watt S. (1971) The regulation of rabbit skeletal muscle contraction. I. Biochemical studies of the interaction of the tropomyosin-troponin complex with actin and the proteolytic fragments of myosin. J. Biol. Chem. 246, 4866-4871

34. Tilney L. G., Kiehart D. P., Sardet C. and TILNEY M. (1978) Polymerization of actin. IV. Role of $\mathrm{Ca}^{++}$and $\mathrm{H}^{+}$in the assembly of actin and in membrane fusion in the acrosomal reaction of echinoderm sperm. J. Cell Biol.77, $536-550$ 